\title{
ИННОВАЦИОННЫЙ ПОДХОД К СОЗДАНИЮ СИСТЕМ ДОСТАВКИ ЛЕКАРСТВЕННЫХ ВЕЩЕСТВ НА ОСНОВЕ БИОПОЛИМЕРОВ
}

\author{
Д.А. Слободова ${ }^{1,2,3}$, Р.М. Горшкова ${ }^{1,2,3}$, Я.В. Гаврилюк ${ }^{2}$, С.А. Панков ${ }^{2}$ \\ 1000 «Мезон», 141982, Россия, г. Дубна, ул. Университетская, 19. \\ 2НОЦ «Физхимбиофарм» Государственного университета «Дубна», \\ 141982, Россия, г. Дубна, ул. Университетская, 19. \\ ЗСПбГУПТД, 191186, Санкт-Петербург, ул. Большая Морская, 18.
}

DOI: 10.19163/MedChemRussia2021-2021-198

E-mail: dar.slobodova@gmail.com

В настоящее время большой интерес вызывают композиционные материалы медико-биологического назначения на основе биополимеров, предназначенные для создания препаратов, применяемых для терапии заболеваний различной этиологии. Основной задачей при этом является сохранение эффективности и снижение токсичности действующих веществ.

Для решения данной задачи разработаны физико-химические и медико-биологические подходы к созданию систем адресной доставки лекарственных веществ (СДЛ) контролируемого высвобождения и пролонгированного действия на основе природных, биологических активных, нетоксичных, биосовместимых и биодеградируемых полимеров - некрахмальных полисахаридов и белков растительного и животного происхождения. Исследованы процессы макромолекулярного комплексообразования компонентов системы, оптимизированы области устойчивости многокомпонентных систем. Изучены физико-химические параметры, как отдельных биополимеров, так и композиций, выявлены зависимости степени захвата лекарственного вещества, прочности, чувствительности, стабильности СДЛ от соотношения компонентов и их характеристик. Используя в качестве модельных препаратов действующие вещества с противотуберкулезной, цитостатической, анальгезирующей, анестезирующей, противовоспалительной, противовирусной активностью созданы как наноразмерные капсулы для инъекционных препаратов, так и микрокапсулы для буккального, сублингвального и перорального применения. В условия in vitro, ex vivo и in vivo изучена кинетика высвобождения действующего вещества из СДЛ, выявлен механизм массопереноса. Установлено, что созданные системы безопасны и их эффективность превышает лекарственные препараты в традиционной форме более чем в 2 - 3 раза. Доказана универсальность разработанного подхода к созданию новых лекарственных форм, не снижающих эффективность действующего вещества и устраняющих нежелательные побочные эффекты, что дает возможность расширить рынок инновационных препаратов. 